\title{
Corrosion Behaviour of 304 Austenitic, 15-5PH and 17-4PH Passive Stainless Steels in acid solutions
}

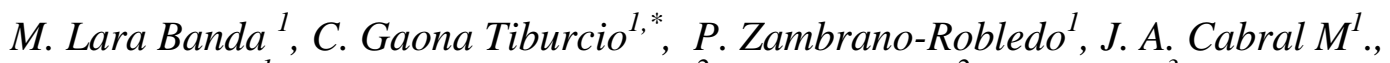 \\ F. Estupinán $L^{1}$., M. A. Baltazar-Zamora ${ }^{2}$, R. Croche B ${ }^{2}$., E. Vera $V^{3}$., F. Almeraya-Calderón ${ }^{1}$. \\ ${ }^{1}$ Universidad Autónoma de Nuevo León, Facultad de Ingeniería Mecánica y Eléctrica, Centro de \\ Investigación e Innovación en Ingeniería Aeronáutica (CIIIA), \\ Av. Universidad s/n, Ciudad Universitaria, San Nicolás de los Garza, Nuevo León 66455, México \\ ${ }^{2}$ Universidad Veracruzana, Facultad de Ingeniería Civil - Xalapa. \\ Circ. G. Aguirre Beltrán S/N, Lomas del Estadio, Xalapa, Veracruz, México, CP 91000 \\ ${ }^{3}$ Universidad Pedagógica y Tecnológica de Colombia, Sede Central Tunja-Boyacá-Colombia. \\ *E-mail: citlalli.gaona@gmail.com
}

doi: $10.20964 / 2018.11 .12$

Received: 13 July 2018 / Accepted: 29 August 2018 / Published: 1 October 2018

The objective of this work was to study is use electrochemical techniques to determinate the growth conditions, characteristics and resistance of passive layers of stainless steel (SS): 304 austenitic, 174PH (precipitation hardening) and 15-5PH. Passivation of the SS was performed in $15 \%$ citric acid at temperatures of 25 and $49^{\circ} \mathrm{C}$. The corrosion kinetics was obtained using the electrochemical technique as potentiodynamic polarization (PP), in a three-electrode system. The electrolytes used were sodium chloride $(5 \mathrm{wt} . \% \mathrm{NaCl})$ and sulfuric acid $\left(1 \mathrm{wt} . \% \mathrm{H}_{2} \mathrm{SO}_{4}\right)$. Passivation in citric acid allows obtain passive layers at temperatures of $49^{\circ} \mathrm{C}$ with immersion times of 30 minutes. In precipitation hardening steels, passive layers up to $360 \mathrm{mV}$ in sodium chloride. Can be obtained. In sulfuric acid, there is a mechanism of passivation - transpassivation - secondary passivation, this due to the high electropositive values of potential.

Keywords: Stainless Steels, Precipitation Hardening, Corrosion, Passivation

\section{$\underline{\text { FULL TEXT }}$}

(C) 2018 The Authors. Published by ESG (www.electrochemsci.org). This article is an open access article distributed under the terms and conditions of the Creative Commons Attribution license (http://creativecommons.org/licenses/by/4.0/). 